\title{
Generaciones después. Mapeando documentales sobre el Holocausto en el siglo XXI
}

Generations later. Mapping documentary cinema about the Holocaust in the 21st century

\author{
Lior Zylberman \\ liorzylberman@gmail.com \\ Universidad Tres de Febrero \\ Argentina
}

\section{Resumen}

La proliferación de imágenes sobre el Holocausto en la era global, así como la renovación generacional en el campo artístico, ha llevado a cambiar la estrategia de la representación del Holocausto: de la sacralización a la desmitificación. En este contexto pensaremos la representación del Holocausto en el documental contemporáneo a través de producciones realizadas desde el año 2000. Así, encontraremos documentales con estilos clásicos y perspectivas formales, con etnografías domésticas y documentales en primera persona, con producciones más próximas al docudrama y al reality show. En lugar de llevar a cabo un análisis exhaustivo, queremos trazar un mapa de algunos de los temas y estilos que surgieron o se consolidaron como una estrategia de representación en este período. Trabajando con títulos de diversas nacionalidades, ordenaremos nuestro análisis a partir de dos temas centrales: Exponiendo la historia, será el primero; e Historias de familias, el segundo.

Palabras clave en español: Holocausto, Representación, Cine Documental, Familia, Historia. 


\begin{abstract}
The proliferation of images of the Holocaust in the global era, as also the generational renewal in the art field, has led to change the strategy of the representation of the Holocaust: from the sacralization to the demystification. In this context we'll think the representation of the Holocaust in contemporary documentary film through productions made since the year 2000. Thus, we'll find documentaries with classical styles and formal perspectives, with domestic ethnographies and documentaries in first person, with productions that are closest to the docudrama and the reality show. Rather than carry out a thorough analysis, we wish to draw a mapping of some of the themes and styles that emerged or were consolidated as a strategy of representation in this period. Working with titles of various nationalities, we will order our analysis from two central topics: Exposing the history, will be the first one; and Family stories, the second.
\end{abstract}

Palabras clave en inglés: Holocaust, Representation, Documentary Cinema, Family, History.

\title{
Presentación
}

El presente trabajo se enmarca en una investigación que se está realizando en el Centro de Estudios sobre Genocidio de la Universidad Nacional de Tres de Febrero, Argentina, siendo el objetivo de la misma el estudio de las representaciones cinematográficas de los genocidios. De ella surge el interrogante en torno a cómo es representado el Holocausto en los documentales del siglo XXI. Para dar cuenta a dicha cuestión, nos hemos propuesto efectuar un primer recorrido exploratorio que busca efectuar un mapeo del tópico antes que adentrarnos a análisis más detallados.

Como señalan muchos autores, desde la década de 1990 la memoria y el estudio del Holocausto ha visto numerosas transformaciones, volviéndose así no sólo "tropos universal del trauma" (Huyssen, 2001) sino también una religión civil "con sus dogmas (el deber de memoria) y sus rituales (las conmemoraciones, los museos)" (Traverso, 2008, p.85). En esa dirección, a través de 
la "americanización del Holocausto" (Novick, 2000; Rosenfeld, 1997), éste ha ingresado no sólo a la cultura popular americana sino también global; así, y tal como señalara Andreas Huyssen, el problema que se plantea en la actualidad no parecería ser el del negacionismo o el olvido sino "la ubicuidad, diríase incluso el exceso de imaginería sobre el exterminio nazi en nuestra cultura" (Huyssen, 2001, p.153).

En su estudio sobre la memoria en la era global, Daniel Levy y Natan Sznaider (2006) piensan que en la actualidad el Holocausto es el prototipo de la memoria cosmopolita. Según estos autores, la cultura, y sobre todo el recuerdo del Holocausto, ya no puede ser pensado exclusivamente dentro de los Estados nacionales no sólo por la crisis de éstos sino porque la memoria de este hecho se encuentra relacionada y en diálogo con otros espacios. Esto no significa necesariamente que el recuerdo en la era global sea homogéneo sino que se encuentra en tensión con las formas memoriales locales y las identidades distintivas, es por eso que los autores se refieren a poder pensar este recuerdo, a partir de Roland Robertson, como parte de los procesos de "glocalización" (Levy y Sznaider, 2006, p.27). En sintonía con lo recién expuesto, podemos decir que si bien existe una mayor producción de documentales sobre esta temática en Estados Unidos, Israel y Alemania, lo cierto es que nuestra investigación nos ha llevado a trabajar con producciones que provienen no sólo de dichos países sino también de Argentina o Francia. En la era global, quizá sea la serie documental Broken Silence, producida por la otrora Survivors of the Shoah Visual History Foundation quien mejor represente este carácter cosmopolita. A partir de los testimonios registrados en distintos países, cinco directores de diversos países realizaron documentales focalizándose en testimonios de sobrevivientes residentes en sus países: Argentina, Hungría, Rusia, Polonia y República Checa.

La proliferación de imágenes del Holocausto en la era global, como también la renovación generacional en el campo artístico, ha llevado a un cambio de estrategia en la representación del Holocausto: de la sacralización a la desacralización (Apel, 2002). Mientras que en la primera corriente podemos pensar a autores como Elie Wiesel o a Claude Lanzmann, en la segunda es posible encontrar a artistas y realizadores que asumen la representación del Holocausto ya sea como una estrategia de recuerdo como también bajo modalidades de representación más amplias que no temen comparar el Holocausto con otros genocidios o con problemáticas raciales, 
nacionales o problemáticas biopolíticas. Para decirlo de otro modo, en el marco de la representación sacra podemos encontrar a sobrevivientes y testigos directos (primera generación), mientras que los que han adoptado estrategias de desacralización pueden ser pensados como " $l a$ generación de la posmemoria" (Hirsch, 2012). Si bien la desmitificación del Holocausto ha sido asociada con el negacionismo o con el antisemitismo, la desacralización a la que dirigen sus reflexiones estos autores no debe ser comparada con esas corrientes: sus ideas tienen como objetivo discutir las posiciones que interpretan al Holocausto bajo la concepción unicista e inimaginable; con ello, también debemos remarcar que en ocasiones la desmitificación puede transitar la delgada línea de la banalización y quizá sea en el cine en donde se pueda observar esta cuestión ${ }^{1}$. En el año 2003, un periodista del New York Times advertía que a causa de la alta oferta de películas documentales sobre el Holocausto se había llegado a una "fatiga" en torno a éste. Los datos eran estrictos: desde 1990 se ha ido estrenando un promedio de un documental cada dos meses; y para continuar demostrando esta sobreabundancia basta con mencionar que en el período 1995-2000 cuatro documentales ganaron su categoría como mejor película en los Oscars (Gewen en Resha, 2015, p.154).

Lo cierto es que también existe un dato fáctico. La producción de imágenes se enfrenta (y se dirige) ante generaciones nacidas ya no sólo luego del Holocausto sino que ya no poseen vínculos directos con sobrevivientes o testigos del nazismo. Por lo tanto, podemos pensar que las estrategias de representación que tuvieron lugar para los contemporáneos quizá no sean las adecuadas o que no funcionen del mismo modo para los sucesores. En consonancia a lo anterior, para nuestra investigación tampoco debe pasar por alto las transformaciones dentro del cine documental. Entre la liberación de los campos de concentración nazis hasta la actualidad hemos asistido tanto a la emergencia de nuevas modalidades de representación (Nichols, 2001) como a nuevas interpretaciones en torno a qué caracteriza al propio cine documental (Bruzzi, 2006; Winston, 2008).

\footnotetext{
${ }^{1}$ Diversos autores, como Tim Cole (2000), se han referido a la desmistificación del Holocausto a partir de una crítica comercial y económica. Sin embargo, nosotros adoptamos la perspectiva problematizada por Apel ya que su indagación posee cierta relación con algunos de los documentales aquí trabajados; su crítica, a su vez, se dirige también a cómo comprender el Holocausto desde la sucesión de las generaciones.
} 
Alrededor del cine sobre el Holocausto se ha dado un ríspido debate que no se encuentra exento de polémicas (Avisar, 1988; Insdorf, 2002). Libby Saxton (2008) ha sabido sintetizar algunos de éstos ya sea desde las posturas de Jean-Luc Godard y Claude Lanzmann o a partir de unos ensayos de Georges Didi-Huberman; en esa dirección, el eje central del debate no pasa por la posibilidad de representar o no, o por su carácter de imposible sino por ciertas implicaciones éticas en el uso de las imágenes. Como señalaron otros investigadores, el debate académico parecería estar dado en torno a si existen "representaciones adecuadas o menos adecuadas" (Burucúa y Kwiatkowski, 2014, p.14).

Resulta importante señalar que en la exploración que llevamos adelante éste debate parecería ocupar un lugar menor. Veremos que en algunos de los títulos que analizaremos no se detienen en torno a narrar, a mostrar o a representar el Holocausto en sí, ese círculo de fuego al que Lanzmann alguna vez se refirió, sino a los efectos del Holocausto: ya no cómo se produjo, qué caracterizó al Holocausto, sino qué implicaciones posee hoy.

En este contexto, en el presente escrito pensaremos la representación del Holocausto en el cine documental contemporáneo a través de producciones realizadas a partir del año 2000. Nos encontraremos así con documentales con estilos clásicos y perspectivas formales, con etnografías domésticas y con documentales en primera persona, con producciones que se encuentran más próximas al docudrama y al reality show, y también con títulos que pretenden seguir el estilo fundado por Lanzmann. Antes que llevar adelante un análisis exhaustivo, deseamos trazar un mapeo de algunos de los temas y estilos que emergieron o se consolidaron como estrategia de representación en este período. Trabajando con títulos de diversas nacionalidades, ordenaremos nuestro análisis a partir de dos ejes temáticos: al primero lo denominaremos exponiendo la historia; el segundo, será considerado como relatos de familia 2 .

\section{Exponiendo la historia}

\footnotetext{
${ }^{2}$ Nuestra investigación también incluye un tercer eje que hemos denominado mirando imágenes; en él, damos cuenta de una serie de títulos donde se revisan, se indagan e historizan imágenes sobre el Holocausto que producto de su uso como imágenes de archivo han ganando fuerza simbólica a la vez que perdían sus propias historias y particularidades.

Cuadernos Judaicos ISSN: 0718-8749 
El registro visual de evidencia de los crímenes nazi fue una de las tareas cardinales de los Aliados a medida que se avanzaba en la liberación de los campos de concentración. Mucho de ese material fue empleado para los documentales que se proyectarían, fundando así un uso del material audiovisual como prueba judicial, en el Tribunal de Nüremberg de 1945 (Delage, 2013). Creando una "pedagogía del horror" el shock visual fue la primera estrategia de representación; sin embargo, ver no era sinónimo de entender y estas imágenes, reproducidas también en noticieros cinematográficos de la época a menudo fueron acompañadas por "un cúmulo de discursos cuyo objetivo explícito era acusar, pero cuyo efecto derivado era atenuar el impacto surrealista, en su sentido literal, de las imágenes, es decir, su paradójica irracionalidad" (Sánchez-Biosca, 2006, p.145). Al mismo tiempo, todo ese registro visual, fotográfico y fílmico, comenzaba también a crear un archivo que con el correr del tiempo sería empleado una y otra vez por diversas producciones documentales.

Con el correr de las décadas, los documentales sobre el Holocausto se adscribieron dentro de una modalidad particular: la expositiva. En esta modalidad, siguiendo la canónica distinción de Bill Nichols (1997), se expone una argumentación acerca del mundo histórico y se suele emplear una voz omnisciente que presenta una narración que funciona para soportar a las imágenes, que trabajan más que nada como ilustradoras del relato. El montaje, en esta modalidad, suele establecer y mantener una continuidad. Siguiendo también a Carl Plantinga (1997), podemos pensar que los documentales de este primer período adoptaron una perspectiva formal (formal voice) ya que no se debe reparar únicamente la posición, el tono, de la voz sino también su punto de vista epistemológico, el tipo de conocimiento que emana.

El siglo XXI no significó necesariamente la ruptura o el abandono total de estas modalidades. Into the Arms of Strangers: Stories of the Kindertransport (Mark Jonathan Harris, 2000) continúa haciendo un contrapunto entre la voz omnisciente, los testigos y las imágenes de archivo. En esa misma dirección, pero ya con un marcado abandono de la voz en off, la mencionada serie Broken Silence viene a representar el lugar global del Holocausto. En términos formales encontramos quizá más continuidades que discontinuidades, pero resulta importante resaltar tres elementos. Primero, el carácter cosmopolita de su producción: además de ser una coproducción entre productoras locales y la Visual History Foundation, la serie presenta historias locales, historias 
micro, a la vez que intenta dar cuenta de la gran narración histórica. Si bien todos los testimonios de los sobrevivientes en los cinco capítulos se remiten a Europa, el documental argentino algunos que vivieron de Luis Puenzo coloca en tensión el antisemitismo nazi con los atentados a la embajada de Israel en 1992 y contra la sede de la Comunidad judía argentina, AMIA, en 1994, ambos hechos sucedidos en la ciudad de Buenos Aires. Un segundo elemento importante que señalar lo encontramos en Eyes of the Holocaust de János Szász. Aquí, además de hacer uso de los testimonios e imágenes de archivo, el documental recurre a una puesta en escena poética que funciona como articuladora: una niña -los sobrevivientes del documental eran niños durante el período del Holocausto- que lee un diccionario titulado de igual manera que el film. Lo novedoso en este documental resulta ser el uso de ciertas imágenes de archivo: para ilustrar las deportaciones se emplea el cortometraje de animación Toccata for Toy Trains (Charles Eames, Ray Eames, 1957). Podríamos pensar dos cuestiones en torno a este recurso: por un lado, la apelación a él se debe al carácter de la mirada, pudiendo el cortometraje reproducir el imaginario infantil, naif, de la narración; por el otro, la necesidad de expresar una emotividad que las imágenes de archivo usualmente no alcanzan a brindar.

Si algo caracteriza a gran parte de los documentales que cuentan con el testimonio de sobrevivientes es su puesta sobria. En estudio o en la comodidad del hogar, el sobreviviente narra sus vivencias mientras es registrado por la cámara; en ocasiones, también se lo sigue a diversas locaciones, como ex campos de concentración o las ruinas del gueto, con el objetivo de que el sobreviviente recuerde in situ sus experiencias pasadas. Además del mencionado film de Lanzmann, The Last Days (James Moll, 1998) es también un claro exponente de esta puesta en escena. En estos documentales no sólo el Holocausto es comprendido como algo sacro sino también la figura del sobreviviente: bajo la "era del testigo" en los documentales el sobreviviente parece ser también una fuente de verdad y de evidencia. El sobreviviente parece no tener emociones, o, en todo caso, sólo emociones que remiten al dolor o al martirio, el sobreviviente “debe contar” y la única emoción eximida ante las cámaras es el llanto.

Los documentales El árbol de la muralla (Tomás Lipgot, 2013), Forgiving Dr. Mengele (Bob Hercules, Cheri Pugh, 2006) y Watermarks (Yaron Zilberman, 2004) presentan algunas alternativas en torno tanto a cómo exponer la historia y a cómo retratar al sobreviviente. El árbol 
de la muralla es un retrato Jack Fuchs, un sobreviviente de Auschwitz que reside en la Argentina. En él, Fuchs no brinda un testimonio sobre su paso por el gueto de Lodz y el campo de Auschwitz sino que reflexiona sobre la experiencia de sobrevivir y dar testimonio. Filmado también en diálogo con otras personas con las cuales medita en torno a ello, el documental sigue al sobreviviente en sus diversas tareas cotidianas, como por ejemplo ir a una facultad a dar una charla; así, el documental no expone ni la historia del Holocausto ni la del propio Fuchs, sino reflexiones filosóficas e históricas. Realizado con cierta libertad formal, la cual le permite a Lipgot entrar en cuadro junto a otros miembros del equipo técnico o generar diálogos entre Fuchs y el director fuera de campo, el sobreviviente también es mostrado cocinando para el equipo técnico. Estos elementos hacen que, a pesar de comprender, por los dichos del propio Fuchs, al Holocausto en términos sacros las estrategias de representación del sobreviviente poseen características más propias de la desmitificación.

En una dirección similar podemos pensar a Forgiving Dr. Mengele. Aquí la protagonista es Eva Mozes Kor, sobreviviente junto a su hermana gemela del campo de Auschwitz. En términos históricos, este documental nos expone la historia en forma más bien clásica, haciendo uso del material de archivo en forma ilustrativa antes que evidencial. Aquí también observamos la vida cotidiana de la sobreviviente, quien además de ser vendedora de bienes raíces fundó el museo y centro educativo CANDLES, acrónimo de Children of Auschwitz Nazi Deadly Lab Experiments Survivors, en la ciudad de Terre Haute, Estados Unidos. Como sugirió Brad Prager (2015, p.115) este documental no plantea ninguna provocación política explícita ni tampoco se destaca por su calidad artística: el documental fue realizado con bajo presupuesto y en ocasiones bordea cierto amateurismo. Si bien nos enmarca el contexto histórico, relatándonos sobre todo el destino de los gemelos en Auschwitz, Forgiving Dr. Mengele no pretende ser una lección de historia: lo sugerente de este documental es su localización en el aquí y ahora. Por un lado, el documental retrata la actividad de la sobreviviente en su organización, su activismo y su deseo de encontrar a más sobrevivientes gemelos. Al retratar la cotidianeidad de Eva, la cámara se permite registrarla en situaciones que no resultan ser las prototípicas para un sobreviviente: en un registro más próximo a la desacralización, Eva no sólo es filmada cocinando para su familia sino también, por ejemplo, en el gimnasio, sudando en la cinta para correr. ¿Cuál es la necesidad de exponer el cuerpo de Eva de ese modo? Bosquejamos dos posibles respuestas: por un lado, para mostrar la 
normalidad y fortaleza del sobreviviente; por el otro, porque en este retrato impera también la lógica del reality show por la cual la cámara no sólo participa de la vida cotidiana del personaje y la privacidad pasa ser un elemento a exhibir, sino porque la intimidad ha pasado a ser un espectáculo (Sibilia, 2008). Pero para que esta lógica funcione como tal, necesita también del conflicto, del choque con otras fuerzas, y ese será el otro nudo central del documental que colabora a desmitificar al Holocausto: Eva, sobreviviente de Auschwitz, está dispuesta a perdonar a los nazis. Eso la llevará a chocar contra otros sobrevivientes, psicólogos, filósofos y rabinos, exponiendo una problemática debatida extensamente en el ámbito de la filosofía pero poco transitado en el cine. El documental nos muestra el momento en que Eva logra dar con Hans Munch, un ex médico de las SS, que a pesar de trabajar en el laboratorio de Josef Mengele se negó a participar de las selecciones en el campo. Junto a él regresó a Auschwitz, en ocasión del 50 aniversario de la liberación de dicho campo, para que firme, ante numerosos testigos, un documento en el cual afirma la existencia de las cámaras de gas; a cambio, ella le extendió una carta de perdón. Tema ríspido en la historia del Holocausto y que le ha traído numerosas críticas a Kor, ella reitera en numerosas oportunidades que el perdón se relaciona con la necesidad de su parte de liberarse de los fantasmas de su hermana y de su propia ira. Podíamos pensar, igualmente, que más que un perdón lo que vemos en el documental es una "transacción" desigual: el perdón a cambio de "verdad" (antes que un "arrepentimiento").

Si el documental anterior expresaba el punto de vista de una sobreviviente en el presente, Watermarks sigue una línea similar. Este documental tampoco se propone exponer lo que fue el Holocausto, sino un aspecto más del antisemitismo en la Europa ocupada. En su documental, Yaron Zilberman se propone contar la historia del equipo de natación femenino del club vienés Hacoaj, y es a partir de la historia de estas seis mujeres que nos ilustramos sobre la experiencia nazi en Austria. De hecho, una de ellas, Judith Haspel, poseía varios records olímpicos, que les fueron quitados al negarse a asistir a los Juegos Olímpicos de 1936 en Berlín -será recién en 1995 que sus marcas les fueran devueltas-. La riqueza de este documental reside en exhibirnos una micro historia dentro de la macro historia sobre el Holocausto rescatando aspectos de la vida judía en Viena y en otras ciudades europeas previo al ascenso del nazismo. Es "otra" historia la que este film nos presenta, una historia centrada más en la cotidianeidad que en los héroes, antihéroes o figuras trágicas del Holocausto. Presentada como una película coral, el relato de la Cuadernos Judaicos ISSN: 0718-8749 
película se construye a partir del testimonio de las mujeres y con imágenes de archivo, sobre todo material proveniente del archivo privado de las ex nadadoras. Antes de presentar una historia "típica judía", nos presenta la historia de mujeres no sólo asimiladas a la cultura austríaca sino que se sentían parte de ésta a pesar del preponderante antisemitismo en aquel país. La historia de la llegada del nazismo a Austria se entrecruza así con las historias personales, con sus vidas pasadas y las actuales, con sus recuerdos y memorias personales. Aunque, o dado que, están desperdigadas en diversos países -Estados Unidos, Israel e Inglaterra- Zilberman le propone a las mujeres otro objetivo: volver a nadar todas juntas, como un equipo, en la pileta en la que solían hacerlo en la década de 1930. Así, el clímax de la película llega no sólo con el regreso de las mujeres a su Viena natal sino con el reencuentro de las mujeres en la mencionada piscina. Planteado este objetivo desde el principio del film, podemos notar que la estructura narrativa del documental queda organizada a partir del propósito de volver a esa pileta; así, antes que el relato gire en torno a una presentación de los hechos históricos, es el drama -en el sentido de acción- el que articula y organiza el montaje del film. De este modo, las últimas imágenes del documental quedan reservadas para las mujeres en traje de baño nadando en la pileta, y lo que en un principio puede parecer pudoroso resulta ser una importante labor de redención para este grupo de mujeres que habían sido despojadas no sólo de un futuro promisorio en el deporte sino también, y por sobre todo, de sus raíces.

Tal como señalan Levy y Sznaider (2006) otro elemento de la ubicuidad del Holocausto se caracteriza por el boom museístico, la proliferación de museos sobre el Holocausto en diversas ciudades occidentales es parte de la memoria cosmopolita en la era global siendo uno de los epicentros los ex campos de concentración devenidos algunos de ellos en museos. En esa dirección $K Z$ (Rex Bloomstein, 2006) se concentra en el campo-museo de Mauthausen: optando por una modalidad de observación, por la cual la cámara parece moverse con la libertad del cine directo, las primeras imágenes de $K Z$ pueden asemejarse a la visita de un shopping o de cualquier otro no-lugar. Bloomstein no emite comentario alguno, quedando su cámara envuelta en la supuesta objetividad que esta modalidad permite. Si bien transcurre gran parte del tiempo observando cómo funciona el sistema de guías en el campo-museo, la cámara también sale a entrevistar a vecinos del campo, viudas de guardias de las SS como también a los propios guías. A pesar de no estar en cuadro y de no emitir juicio alguno a través de su voz, el montaje resulta 
sumamente expresivo: el plano del cartel en la ruta de McDonald's Mauthausen no sólo enuncia cierto posicionamiento del realizador ante su observación sino que también expresa la tensión que hay en la zona alrededor del campo. El relato se abre así en varias líneas: una es la que sigue a los guías en su tarea, donde vemos grupos de diversas edades, desde estudiantes hasta un grupo de ancianos que han venido como turistas; en las visitas guiadas la cámara logra capturar imágenes reveladoras: el museo-campo posee las características de cualquier lugar turístico, la gente se saca fotos, incluso posa, junto a los crematorios, se sacan autofotos y selfies y vuelven a sacarla cuando notan que no salió del todo bien. Otra línea argumental se asienta en entrevistas con los vecinos que viven en los alrededores del campo y en la propia ciudad de Mauthausen presentando una dicotomía que al parecer no es tal: ¿qué significa vivir en un sitio como este? ¿puede vivirse con "normalidad" en esta ciudad? A pesar de las respuestas esquivas de varios vecinos, claramente la respuesta es sí; todos emiten una opinión sobria dando cuenta de la particularidad del lugar al cual aceptan bajo la idea de que hay que dejar el pasado atrás. Esta tensión entre pasado y presente se observa en las registradas en Frellerhof, la cantina que está ubicada cerca del campo. A dicha cantina solían ir los SS y ahora sigue expendiendo sidra y funcionando como un bar típico austríaco, con shows de baile y música. Con todas estas voces, el documental transita en torno a una pregunta fundamental: ¿cómo lidiar con el pasado? ¿acaso toda una ciudad debe quedar suspendida en el pasado? Como señala Prager (2015, p.36), a diferencia de otros documentales donde los grupos representados son las víctimas y los perpetradores, en $K Z$ son los turistas y los locales, siendo estos últimos los que aún se encuentran fascinados con la larga historia de Austria, incluso previa a la modernidad, los representados; para ellos, el nazismo fue un episodio marginal a ser olvidado.

Al registrar el trabajo de los guías, se observa que su labor resulta más mecánica que emotiva, teniendo incluso la obligación de dar cuenta de los detalles escabrosos con el objetivo de "ofrecer un simulacro de la angustia de los ex prisionaros" (Prager, 2015, p.39). Muchos de los jóvenes que trabajan como guías lo hacen como parte de su servicio social, siendo algunos de ellos nietos de ex SS. La constante repetición de un mismo relato, estar día a día narrando el horror lleva también a que los guías enfermen de depresión, uno de ellos incluso nos cuenta que ha estado tomando antidepresivos y se ha vuelto alcohólico. El documental también nos sugiere cómo los ex campos de concentración se han vuelto centros turísticos cosmopolitas ya que no sólo asisten 
turistas de todos los rincones de Austria sino también de otras regiones de Europa, Estados Unidos o de Sudáfrica. Con todo, el y a pesar del cinismo que puede poseer la mirada de Bloomstein, $K Z$ parece no criticar ni censurar a los turistas en sí, sino los posibles “comportamientos turísticos" de algunos de ellos.

En la segunda edición de su libro New Documentary, Stella Bruzzi (2006, p.43) da cuenta sobre las alteraciones del lugar del archivo en el cine documental desde la primera edición de su estudio en el año 2000. Para ella, el cambio más importante es el significativo aumento del uso de la reconstrucción dramática como complemento o, incluso, como reemplazo del material de archivo. Ahora bien, ¿cómo pensar esta tendencia en el marco de la representación del Holocausto?

Al observar un documental que hace uso de las recreaciones sabemos que éste no "miente" ni falsea la historia ya que, en última instancia, como han señalado varios autores, el cine documental también se caracteriza por el modo en que lo vemos. Bruzzi señala que las recreaciones han cambiado el modo en que somos "invitados a responder emocional $e$ intelectualmente ante las imágenes en cuestión" (2006, p.44) pero también, en términos positivos, podemos ver una función liberadora: para los documentales históricos, sobre todo, la recreación permite ir más allá del archivo. En ocasiones las imágenes de archivo resultan limitadas y no permiten ilustrar o brindar evidencia de lo que se desea narrar, esta limitación también se relaciona con el reciclado de imágenes, que ya han sido utilizadas en diversos documentales desprendiéndose así de su propia historia; finalmente, el uso de las recreaciones se debe también a que ya no quedan testigos que puedan dar cuenta de los hechos.

En la representación del Holocausto en el documental contemporáneo podemos observar cierta tendencia que se caracteriza por usar la recreación ya no como "relleno" o como forma de interpretar el testimonio sino como parte fundamental de la estrategia de representación. En nuestra investigación hemos encontrado al menos tres producciones que, con el objetivo de exponer la historia, apelan a la reconstrucción. Resulta difícil colocar a estos documentales bajo una etiqueta en particular; es decir, pensar si son docudramas, docuficciones o documentales dramáticos (Paget, 2011), sin embargo, estos tres títulos se caracterizan por combinar los elementos característicos del cine documental con la ficción. 
Oro nazi en Argentina (Rolo Pereyra, 2004) se basa en las investigaciones del periodista argentino Jorge Camarasa que intentan demostrar los vínculos entre la Alemania nazi y el gobierno del presidente Juan Perón, esta relación se sostendría tanto con el asilo en a la Argentina de criminales de guerra como también el lavado de dinero nazi. El documental tiene como objetivo denunciar el entramado político que lo posibilitó, y para ello Camarasa, quien en el documental se comporta como un detective, buscará pruebas en Argentina, España, Alemania e Italia. De este modo, la trama del documental se construye como una película de espías, donde el protagonista, junto a su equipo de trabajo, tiene como objetivo descubrir una intrincada red de conspiraciones. Ahora bien, de toda esa investigación apenas existen documentos escritos y, desde luego, nulo material audiovisual, ¿cómo llevar adelante entonces un documental audiovisual sin imágenes? Empleando, como estrategia principal de representación, la recreación. En ese sentido, las recreaciones funcionan efectivamente como capas de ficción ya que éstas funcionan más en el terreno de la suposición que de la presuposición. Pero para no perder fuerza veritativa, el documental recurre a dos elementos que le darán seguridad retórica: la entrevista a varios especialistas e investigadores que autorizan y fundamentan la perspectiva de Camarasa, y la voz en off omnisciente, objetiva y aséptica.

Una estrategia similar seguirá Laurence Rees en Auschwitz: The Nazis and the Final Solution (2005). Productor de la BBC e historiador, Rees ya había realizado una serie de documentales en torno a Segunda Guerra Mundial y el nazismo, entre ellos The Nazis: A Warning From History en 1997. En ese documental la estrategia de representación se sostenía a partir del empleo de imágenes de archivo, utilizando gran cantidad de metraje a color, y entrevistas. El relativo giro novedoso que proponía Rees en esta historia del ascenso y caída del nazismo no era su interpretación histórica sino a cómo era expuesto, a partir de qué voces se presentaba: la de los perpetradores. Rees sostuvo que muchos de los films sobre el Holocausto tienden a concentrarse en los sobrevivientes y en los testimonios de éstos, para su serie, en cambio, entrevistó a gente que estuvo comprometida con el nazismo, que creía en su programa, y "luego preguntarles por qué hicieron lo que hicieron” (Rees, 2005). Para Auschwitz... asistimos a un cambio formal importante: la reconstrucción pasa a ser la estrategia de representación fundamental. Si bien esta diferencia formal entre ambas obras es notoria, también no debemos dejar de lado los años de producción de cada serie; en la década de 1990, como señala Bruzzi, resultaba "inconcebible que 
Rees usara como recurso la reconstrucción" (2006, p.46). La serie, entonces, se sostiene a partir de cuatro recursos: un leve uso, tanto a color como en blanco y negro, de imágenes de archivo escasamente vistas, entrevistas a sobrevivientes y a ex nazis, como por ejemplo el recientemente juzgado ex SS Oskar Gröning, meticulosas recreaciones y un también novedoso uso de imágenes computarizadas para reconstruir el campo y las cámaras de gas; en el montaje final, las imágenes digitales reconstruidas se intercalan y sobreimprimen con registros actuales de Auschwitz. Con todos estos recursos, Rees se propone narrar la historia del campo, desde su origen hasta su transformación a campo de exterminio, en paralelo tanto a los otros sucesos que caracterizaron al Holocausto como los destinos de la guerra. En los diversos capítulos que componen la serie, las reconstrucciones y recreaciones no son presentadas bajo una puesta tendiente a la espectacularización sino que las imágenes creadas parecerían venir a ilustrar las investigaciones realizadas por Ian Kershaw o Robert Jan van Pelt, asesores históricos de la serie; así, tanto las imágenes computarizadas, basadas en los planos del campo y de las cámaras de gas, como cada palabra e imagen no tienden a ser dramatizaciones sino una puesta en escena de otras fuentes documentales. Si bien observamos a actores interpretando a Rudolf Höss o a Heinrich Himmler, un marcado elemento de autoridad resulta ser la voz en off, una narración con aires cientificistas donde cada intervención es justificada con la cita de una fuente. De este modo, Auschwitz: The Nazis and The Final Solution puede ser pensado como el ingreso de los recursos típicos de los documentales históricos de señales como Discovery o History Channel a la representación del Holocausto, una nueva forma de exponer la historia ha quedado consolidada para narrar el evento del siglo XX.

Finalmente, en esta sección debemos mencionar a Das radikal Böse (Stefan Ruzowitzky, 2013), un film que sigue las sendas trazadas por los otros dos documentales. La exploración que lleva adelante este título tiene su fundamento en una pregunta que ha desvelado a la filosofía y a la psicología: ¿por qué la gente común puede volverse asesinos de masas? Para responder a ello, se concentra en exhibir la historia de los Einsatzgruppen que fusilaron a millones de judíos en la Unión Soviética; sin embargo, el film de Ruzowitzky no se detiene únicamente en ese caso sino que trata de explorar en forma más amplia la propensión a hacer el mal. Prácticamente sin recurrir a imágenes de archivo, Das radikal Böse se sostiene fundamentalmente a partir los recursos de la dramatización y la entrevista, y éstas últimas serán las que precisamente le dan el 
carácter documental a esta producción. Así, son las entrevistas realizadas a personalidades destacadas que han investigado la temática como Roy Baumeister, Christopher Browning, Robert Jay Lifton o Patrick Desbois las que le dan la fuerza veritativa y los fundamentos a las imágenes recreadas. Las dramatizaciones de la tarea fusiladora irán en contrapunto con voces en off anónimas que leen extractos de "cartas, diarios y protocolos", y si estas tienden a ilustrar el caso histórico, otras serán empleadas para ilustrar y explicar en imágenes diversos experimentos -el de Milgram o el de Zimbardo, por ejemplo- o teorías en torno a la obediencia de órdenes criminales.

Los documentales aquí expuestos nos permiten observar diversos cambios en la representación del Holocausto en el cine documental contemporáneo. Podemos pensar un desplazamiento en la exposición de historias, ya no siendo necesario contar qué fue este hecho sino que ahora asistimos a un acercamiento hacia microhistorias, historias laterales o bien sus consecuencias sociales. La desmitificación ha llevado también a que estrategias de representación del documental científico o de los docudramas televisivos sean también empleadas para la representación del Holocausto, un evento histórico que parecería estar al margen de toda concepción ficcionalizante dentro del cine documental.

\section{Relatos de familias}

La otra tendencia que exploraremos se concentra en la familia, en las relaciones familiares. Si bien durante un tiempo el tema de las generaciones fue abordado casi en exclusiva por el cine de ficción y en el campo de la literatura y el psicoanálisis, el cine documental no estuvo exento de retratar el doloroso legado con el que tuvieron que confrontar los hijos de los sobrevivientes del Holocausto. Las tensiones con el pasado en la familia de ex nazis comenzó a ver la luz hacia fines de la década de 1980 y principio de la de 1990 con la publicación de una serie de textos los cuales indagaban a los descendientes de los jerarcas nazis más conocidos como los hijos de Hans Frank, Rudolf Hess, Herman Göring, Josef Mengele o Adolf Eichmann (Posner, 1991).

A partir de lo recién mencionado, resulta sugerente encontrar una serie de documentales contemporáneos que se hacen eco de esta temática pero ya no, o no solamente, para retratar los problemas de la sucesión de generaciones en las familias de las víctimas. Esta serie de documentales llevan a la pantalla las relaciones familiares postnazismo, específicamente en 
familias donde alguno de sus miembros estuvo vinculado con el nazismo. Los cinco títulos que hemos recabado pueden ser pensados en consonancia con cierto giro proveniente en los estudios culturales y visuales; en éstos, se han detectado y analizado un creciente número de producciones artísticas que tienen como protagonistas a los perpetradores (Adams y Vice, 2013).

Inheritance (James Moll, 2006) no puede ser pensado por fuera de los resonancias de Schindler's list (Steven Spielberg, 1993). No sólo porque James Moll estuvo involucrado, como director o productor, en algunos documentales para la fundación creada por Spielberg sino también porque la protagonista de este título es Monika Hertwig, la hija de Amon Göth, el oficial de las SS que sirvió de comandante en el campo de Plaszow y uno de los personajes principales en el film de Spielberg.

Las primeras imágenes son de la residencia de Göth en el campo y este lugar tendrá un espacio de importancia en el documental; luego de éstas, el montaje se dedica a elaborar una presentación de la vida actual de Monika. El pasado se hace presente con imágenes de archivo, lo mismo que la figura paterna, una figura que ha sido desconocida para ella gran parte de su vida. Sin embargo, el flujo narrativo es interrumpido por Helen Jonas-Rosenzweig, una sobreviviente del campo de Plaszow. Es que el objetivo del documental no es narrar la historia de Monika sino ir un poco más allá. La propuesta por parte del director es bastante explícita, el desarrollo del documental no podría haber sucedido sin su intervención en la trama: el objetivo del film es reunir a ambas mujeres en lo que queda hoy del campo. Armado a partir de un gran montaje paralelo, finalmente las mujeres se encontrarán y, al parecer, Monika logrará exorcizar el fantasma de su padre. Ella tenía diez meses de edad cuando su padre fue ejecutado en 1946 al ser condenado culpable por crímenes de guerra, pasando toda su vida con una idea de su padre construida a través de su madre. La relación con Amon ha sido siempre una relación mediada por otros, por objetos e imágenes; y es también a partir de una mediación que se entera de "la verdad": el film de Spielberg la hizo ver a su padre de otro modo. La pregunta que se formula Monika es la misma que se preguntarán de algún que otro modo todos los hijos de padres nazis: ¿debo amar a mi padre? La potencia de las posibles preguntas y formas de desarrollar sus posibles respuestas quedan desvanecidas, a nuestro criterio, por la forma que adopta este título. Su realización se 
emparenta más a la de un reality show que a otro tipo de documental y la apelación a este estilo nos permite remarcar el tenso carácter desacralizador que propone.

Si Inheritance se asemeja a la serie True Life de MTV se debe a cómo se lleva adelante su realización y montaje. Luego de presentar el objetivo del documental, las mujeres se preparan para el viaje, llegando así a Polonia; para ello, las cámaras las filman en sus preparativos, en su vuelo y en su llegada, alternando siempre con entrevistas a ambas, estas instancias dejan de ser espacios de reflexión o testimonio para ser opiniones sobre las acciones que han realizado o están por hacer. Una vez llegadas a Polonia ambas mujeres mantienen un diálogo telefónico registrado a dos cámaras: ¿hay lugar en este documental para lo espontáneo? Las cámaras parecieran estar alertas al choque entre ambas mujeres: Monika hace justicia a su padre, trata de entenderlo, Helen no da cabida a ninguna de las reflexiones de su acompañante; Monika, por extensión, parecería que sólo debe pedir perdón: así, en una sala de la Villa la tensión estallará. Si bien la preguntas que Monika trae resultan sumamente complejas para analizar y desarrollar, el encuentro entre ambas mujeres resulta incómodo, no por ellas sino porque no se comprende la necesidad de este encuentro en tanto evento extrafílmico; es decir, el evento sólo parece tener sentido para las cámaras. Al finalizar el film, y más allá de las conclusiones a la que Monika y Helen pueden arribar en sus comentarios sobre el viaje, ¿qué resultó de toda esta experiencia? ¿Acaso funcionó el viaje para llevar adelante una catarsis, algún tipo de terapia, o todo resultó ser una exhibición de la intimidad para las cámaras?

Monika Hertwig también es una de las protagonistas de Hitler's Children (Chanoch Ze'evi, 2011), en este documental su testimonio y sus preocupaciones parecen ser más profundos. Allí plantea también, como en el otro film, la tensa relación con su madre y cómo esta negara la realidad de lo que había acontecido en el campo. Hertwig también comenta cómo la relación entre madre e hija se vio afectada por la propia relación de su madre con su padre. Hitler's Children, entonces, se propone narrar cómo generaciones posteriores de jerarcas e importantes figuras del nazismo lidiaron con el peso del pasado, ellos son: Katrin Himmler, sobrina nieta de Heinrich, Rainer Höss, nieto de Rudolf, Bettina Göring, sobrina nieta de Hermann, Niklas Frank, hijo de Hans Frank, y la ya mencionada Monika Hertwig. 
Más próximo al cinéma vérité, el documental desarrolla una historia coral a partir de entrevistas y seguimiento a los personajes. El foco de atención no radica en la historia de los predecesores sino en sus descendientes en el presente. La gran cuestión que atraviesa a todos ellos es cómo lidiar con un apellido, con un pasado, ligado al nazismo y el exterminio. Todos los protagonistas han transitado o aun atraviesan un camino de culpa y, a su vez, una voluntad de torcer su propio destino. Katrin Himmler ha estudiado ciencias políticas y su investigación en torno a su propia familia, publicada en libro bajo el título Los hermanos Himmler, le permitió comprender su pasado. Ella no oculta sus orígenes y como tantos otros descendientes de nazis, quizá como forma de reconciliarse con su historia familiar, de hacerle frente y torcerla, se casó con un israelí de origen judío proveniente de una familia masacrada en el Holocausto. El hijo de ambos lleva consigo una doble herencia, la del perpetrador y la de víctima, y es ese hijo el que ha motivado a Katrin a contarle todo sin ocultar nada. Un caso más extremo quizá sea el de Bettina Göring. Además del deseo de acercarse a los judíos, Bettina decidió mudarse a Santa Fe, Nueva México, en Estados Unidos para dedicarse a trabajar con hierbas medicinales con el objetivo de iniciar una nueva vida. Para cumplir esa meta decidió, junto a su hermano, someterse a una operación de esterilización con el fin de no propagar el apellido Göring, terminarlo - exterminarlo si se quierecon ella.

Si en Inheritance la villa de Göth era el espacio para producir ese movimiento de elaboración del pasado, para Rainer Höss en Hitler's Children eso se produce en Auschwitz. Para él, el estigma de tener como abuelo a uno de los asesinos en masa más importante de la historia no ha sido fácil de sobrellevar. El documental retrata su elaboración del pasado como un viaje de transformación, de asumir su lugar en la historia para revertir el destino del apellido. Con el recuerdo de unas fotografías de su padre jugando en un jardín de la casa en el campo de Auschwitz, Rainer decide ir hacia allá para encontrarse con las huellas de su pasado familiar. La cámara registra ese viaje, incluso ésta se entromete en los momentos más íntimos deseando captar todo: en el momento de mayor angustia para Höss, cuando desea un momento de intimidad, la cámara busca con un zoom sus lágrimas, pareciendo desear comprobar que su dolor es genuino. Finalmente, su jornada finaliza en un encuentro con jóvenes y un sobreviviente que han ido a visitar el campo. Ante todos ellos, él pide perdón por su abuelo y por él mismo, por su apellido, por quién es. 
Para todos estos personajes, el antecesor, el pasado, se comporta como un fantasma que los acosa. Muertos hace tiempo, la gran mayoría debido a la cumplimentación de la condena a muerte por sus crímenes, estos antepasados parecerían salir de una tumba mal cerrada. En la teoría del fantasma desarrollada por los psicoanalistas Nicolas Abraham y Maria Torok, este fantasma acosaría a un miembro de la familia a partir de un no-dicho convertido en secreto y convirtiendo su cuerpo en una cripta (Abraham y Torok, 2005, pp.339 y ss.). Si bien en este caso el secreto que llevan es un secreto a voces, la imposibilidad de hablar de ello durante años es lo que lo ha convertido en tal. En cierto sentido, el documental permite retratar las diversas formas terapéuticas que los diversos descendientes llevan adelante con el objetivo de liberarse de esa cripta. Para deshacerse de ella no alcanza con identificarla sino también nombrándolo, diferenciándose del fantasma para permitir que parta.

Harlan. In the Shadow of Jew Süss (Felix Moeller, 2008) no es solo una biografía de Veit Harlan, el infame director de Jud Süß (1941), quizá la más refinada película de propaganda nazi. De todos los films realizados por los nazis con ese objetivo, el de Harlan fue la que contó con más éxito de público volviéndose también de visión obligatoria para todas las $\mathrm{SS}^{3}$. Por esa película, Harlan fue procesado como criminal de guerra siendo el único artista alemán que fuera sometido a ello. Pero la película de Moeller no busca ser solamente una biografía sobre este director, explora también a la propia familia Harlan y su relación con Veit, cómo lo ven, cómo lo interpretan, cómo lo justifican. ¿Fue un nazi convencido o fue una "víctima" de las circunstancias? ¿Cuánto del trabajo creativo en ese film salió de él y cuánto de éste fue hecho por obligación? ¿Estamos ante un "Fausto"? Esta historia bien podría haberse contado en términos objetivos o como un documental más bien clásico. Estéticamente posee todas esas características, pero temáticamente incorpora ya no la voz de expertos para opinar y dar cuenta del personaje principal sino a su propia familia. Por lo tanto, el documental es, ante todo, un documental familiar y cómo ésta trata de elaborar el pasado, de liberar al fantasma.

La familia Harlan es numerosa, se compone por hijos e hijas (de los diversos matrimonios de Veit), sobrinos y sobrinas, nietas y nietos. Todos ellos tienen visiones diferentes sobre el director:

\footnotetext{
${ }^{3}$ Éxisten varios trabajos académicos que han investigado la historia de este film. El libro de Susan Tegel,
} Jew Suss. Life, Legend, Fiction, Film, es uno de lo más precisos al respecto. 
mientras que Thomas, uno de los hijos, adopta una mirada sumamente crítica sobre su padre, Caspar, otro de los hijos, opina que su padre es su padre y no debe ser criticado. El documental expone también las contradicciones y las tragedias para elaborar el trauma. Maria Körber, una de las hijas, no posee una posición crítica respecto a su padre pero sin embargo para hacerse camino en su carrera de actriz adoptó el apellido de su madre. Susanne, otra de las hijas, llegó a casarse con un fotógrafo judío en 1953, dicen que como forma de revertir la vergüenza familiar. Resulta interesante observar a las generaciones más jóvenes: algunas de las nietas de Caspar pueden llegar a imaginar a su abuelo casi como una víctima, mientras que Alice, la hija de Thomas, posee una mirada más crítica y más interesada con la historia familiar; en esa dirección, podría pensarse que ese interés es una marca familiar, sin embargo, Chester, el otro hijo de Thomas, no muestra interés por su familia, parece no sentirse señalado por el peso del apellido. Este documental resulta así de sumo interés para observar la memoria familiar en funcionamiento, cómo se construye el imaginario familiar en las diversas generaciones y cómo cada una de éstas se posiciona ante el pasado. En este caso, lo sugerente es observar también la heterogeneidad de esta familia, permitiendo no arribar a ninguna conclusión única y concreta. Sin embargo, resulta interesante advertir, en consonancia con algunos estudios sobre la memoria familiar nazi (Welzer, Moller, y Tschuggnall, 2012), que son recién los nietos los que pueden ver a su abuelo como una posible "víctima". Por otro lado, se aprecia que esta familia, por discrepancias internas -que en cierto sentido se observan en las interpretaciones sobre el pasado- no conforma una comunidad de recuerdo, como familia sólo parecen poseer un apellido y un pasado en común antes que un futuro en conjunto. Es por eso que también las diversas cavilaciones en torno a Veit Harlan se encuentran abiertas a operaciones de recontextualización del pasado; eso no significa que la historia sea tergiversada o negada sino que en dicha operación el lugar de Veit Harlan es sometido a reinterpretaciones.

Dado que las relaciones familiares se caracterizan por ser absolutamente complejas, la vida de un individuo al interior de una familia se ve regida no solo por su propia psicología sino también por las reglas que rigen la existencia de la unidad familiar. En ocasiones, como en el documental recién mencionado, la familia ampliada se encuentra en crisis pero existen lazos entre núcleos filiales más pequeños. En ese sentido, es que en la sucesión de generaciones, en las relaciones entre padre e hijos, se establece lo que Ivan Boszormeny-Nagy denominó "deuda existencial", Cuadernos Judaicos ISSN: 0718-8749 
nuestra existencia resulta inconcebible sin la de ellos: "mi padre será mi padre, aun cuando esté muerto y su sepultura se encuentre a miles de kilómetros de distancia" (Boszormenyi-Nagy y Spark, 1983, p.23). Esta frase, que bien podríamos haber escuchado de boca de Monika Hertwg, también la podemos escuchar en los documentales con los que queremos cerrar este escrito.

En los vínculos familiares, Boszormeny-Nagy también se refirió a las lealtades familiares, que se componen, entre otros elementos, de los pensamientos y motivaciones de cada integrante, eso lleva a que cada familia desarrolle también un concepto particular de justicia y de justicia familiar. El otro concepto clave en su teoría es del de parentización, una idea que se encuentra asociada con la de deuda e inversión; es decir, la deuda que cada niño contrae con sus padres por el amor, el afecto, los cuidados, etc. que le fueran dados. Esta deuda sólo se salda en forma transgeneracional: aquello que recibimos de nuestros padres lo devolvemos a nuestros hijos. Estas tensiones en las "lealtades indivisibles" es lo que caracteriza a los documentales sobre familias de descendientes nazis: con lo recién expuesto, la pregunta principal sin dudas es qué hacer con esa herencia, cómo ser leal cuando la moral familiar no es compartida, qué poner primero: ¿la lealtad familiar o una moral universal? Estos dos polos parecerían ser en los que oscilan los dos últimos documentales que comentaremos.

Alejados de los estilos que veníamos observando en las producciones anteriores, The Flat (Arnon Goldfinger, 2011) y 2 oder 3 Dinge, die ich von ihm weiß (Malte Ludin, 2005) se corresponden a los documentales en primera persona, una modalidad que se ha vuelto habitual en los documentales contemporáneos. Si ambos documentales presentan situaciones en el seno familiar por la cual todo el conjunto debe lidiar con el asunto, la cámara parecer actuar como la pluma que escribe momentos autobiográficos ${ }^{4}$ metiéndose en situaciones ríspidas, en los secretos y en los mitos familiares. Por cómo se despliega la familia, ambos documentales pueden ser pensados también como "etnografías domésticas", siguiendo a Michael Renov (2004, pp.216-229) esta idea puede resultar reveladora ya que nos permite comprender a ambos documentales como interrogaciones autobiográficas y a la vez la documentación de la vida de Otros, siendo estos otros su propia familia. En estos films, lo cercano se vuelve entonces lejano, y dadas las

\footnotetext{
${ }^{4}$ Sobre el cine documental autobiográfico, véase Renov (2004, pp.104-119).
}

Cuadernos Judaicos ISSN: 0718-8749 
relaciones de parentesco, el sujeto y el objeto (e incluso subjetividad y objetividad) se encuentran encarnadas una con otras.

Con las distinciones recién comentadas, The Flat nos presenta su relato como una historia de detectives pero a diferencia de aquellas, aquí no hay asesino a descubrir sino que la misión es develar un secreto familiar. Lo sugerente es que dicho secreto asume la forma de fantasma en el propio proceso de investigación teniendo que luchar contra las lealtades invisibles.

Al morir su abuela, Gerda Tuchler, Goldfinger junto a otros integrantes de la familia comienzan con la tarea de limpiar el departamento en el que habitó por casi setenta años. Junto a su marido, un importante juez alemán, había emigrado a Palestina durante la década de 1930 escapando de las primeras persecuciones nazis. Al encontrar entre los objetos varios elementos que remiten a Alemania, Goldginfer se intriga al hallar un diario alemán de la época en la cual notifican el viaje de un nazi a Palestina con el objetivo de establecer contacto con líderes sionistas. En ese diario, se informa que Leopold von Mildenstein, el mencionado oficial SS, contó con la colaboración de Kurt Tuchler... Este hecho llevará a develar el gran secreto de sus abuelos: no sólo trabaron amistad con un nazi antes de la guerra, sino que continuaron esos lazos, compartiendo viajes y otros momentos de placer entre ambas parejas luego de la guerra, luego del Holocausto. ¿Qué relación podía tener este nazi, que había sido el jefe de la oficina para asuntos judíos de la SS antes que Adolf Eichmann, con sus abuelos?

Goldfinger inicia así un viaje tanto al interior de su familia como hacia Alemania, para dar con Edda, la hija de von Mildenstein. En los viajes, la historia va cobrando forma ya que Edda puede aportar información que la propia familia de Goldfinger desconoce. Resulta sugerente ver a la madre reticente ante toda esta historia, como miembro de la segunda generación afirma que no podía preguntar, ni siquiera se pensaba en hacer preguntas sobre el pasado. Arnon, ya desde otra posición generacional, se indigna ante su madre. Si ésta le debe su lealtad a sus padres y por lo tanto no acepta pensar críticamente la relación de éstos con un nazi, algo similar alcanza a registrar la cámara en el caso de Edda. A medida que la investigación avanza, Goldfinger consulta archivos y logra recabar más información sobre el nazi. La historia familiar de Edda se ha construido en torno a una figura que no formó parte del exterminio, que al dejar su puesto en esa oficina se retiró. Sin embargo, Goldfinger encuentra documentación que muestra que su padre 
escribió, luego de dejar su cargo oficial, en Der Angriff, el diario fundado por Goebbels. Para Edda también hay lealtades, ella se niega a revisar críticamente la historia de su padre, un nazi "que no tuvo nada que ver" con el Holocausto. De hecho, resulta sugerente ver que en ningún momento Edda habla de la afiliación y pertenencia de su padre al nazismo, siempre se referirá a él como a su padre y nunca al oficial de las SS. En cambio resulta sorprendente algunas declaraciones del marido de ella; como sugirió Boszormenyi-Nagy, si bien las lealtades entre parientes políticos pueden ser reforzadas a partir del nacimiento de hijos, éstas pueden resultar más débiles: quizá esta sea la razón por la cual el marido de Edda, en ciertos momentos que parecen registrados off the record, puede arrojar algunas interpretaciones sobre el pasado nazi de su suegro.

Hacia el final, Goldfinger le lleva más documentación a Edda. Él le pregunta si quiere saber más sobre la historia, pero ella le responde que le gustaría "ver los diferentes lados también", una historia completa para que tanto su padre como los abuelos de Goldfinger sean los cómplices en el crimen. Quizá la respuesta al por qué de ese extraña relación nunca quede respondida y quedará como un secreto pero el viaje le sirvió también a la familia para abrir su propio pasado y conocer la historia familiar.

Finalmente, la otra película que se adentra a los recovecos de la memoria e historia familiar es el documental de Malte Ludin. 2 oder 3 Dinge... también posee las características de una etnografía familiar y del documental en primera persona; pero a diferencia del de Goldfinger, el de Ludin resulta ser más confrontativo al interior del seno familiar. Ya en las primeras tomas, cuando Ludin, enfrenta a su hermana, se puede apreciar el tono que tendrá el documental:

Es mi derecho ver a mi padre como quiero verlo. No se me ocurre verlo de otro modo sino como lo veo. Es mi derecho. No me puedes quitar eso. Tienes tu propio punto de vista y lo lamento... Si pensaste que puedes cambiar algo con esta película, entonces sacaste la conclusión equivocada.

A diferencia de otros "niños de Hitler" en la familia Ludin las posiciones están bien marcadas. En este documental no hay secreto a develar, todo está servido; el propio Ludin lo narra en off al inicio: "esta es la historia de mi padre, un criminal de guerra, y de mi madre, mis hermanos, 
sobrinas y sobrinos". 2 oder 3 Dinge... es una saga familiar donde se despliegan puntos de vistas disímiles e interpretaciones disonantes. En el corazón de esta saga está el padre, Hanns Ludin, miembro de las SA que sobrevivió a "la noche los cuchillos largo" y diplomático, como tal fue nombrado embajador en la República de Eslovaquia en 1941. Una de sus actividades principales en su puesto fue la de instigar a dicho país de cumplir con las deportaciones de mano de obra esclava. La disputa entre hermanos claramente se concentra en pensar al padre como criminal de guerra o no. Barbel, una de las hermanas, se niega a pensarlo de ese modo porque en forma indirecta ella será hija de un criminal de guerra y no quiere llevar ese estigma como la marca de Caín.

Más próximo a la visión del film sobre Veit Harlan, 2 oder 3 Dinge... logra entrelazar la historia pública con la privada. De este modo, para desentrañar la historia familiar Ludin apela a material de archivo para exponer fotografías de su padre en mítines o en reuniones oficiales como también audios de discursos, asimismo nos muestra imágenes del juicio al que fue sometido en 1947, siendo esas las imágenes finales de su padre. El archivo familiar resulta ser otro de los recursos, sobre todo filmaciones antiguas de su madre Erla; y si su madre no fue filmada especialmente para el documental, se debe a que Malte esperó para hacer este film a que ella muriera ya que sólo podía llevar adelante semejante revisión familiar luego de su partida: quizá sería muy doloroso para ella ser testigo de los posibles enfrentamientos entre hermanos.

Presentados todos los protagonistas del film, la trama que se hilvana se concentra en dos claros ejes: uno intenta reconstruir la actividad del padre, volviendo Ludin a Eslovaquia para hacer sus pesquisas; el otro gira en torno a la discusión familiar si Hanns "sabía o no", es decir si estaba al tanto del exterminio. Pero el relato gira en torno a otras actividades del ex nazi, como su intervención en la arianización de propiedades de judíos. Para las hermanas, que a excepción de Andrea son todas mayores que Malte, la posición de éste resulta incómoda y traicionera: al padre se lo debe respetar. En el desarrollo de la historia, Malte también se entrevista con sus sobrinos, notando que sus opiniones no poseen una toma de posición sino que critican la actitud de los padres y la abuela de no haber lidiado con el pasado y dejarles a ellos esa herencia de complejos e inseguridades. Es por eso que la posibilidad de hablar sobre el pasado les resulta más catártico a los jóvenes que a los hijos de Ludin. 
Con un montaje que entrecruza el pasado con el presente, sugiriendo que ese pasado aún se encuentra vivo en el presente, Ludin lleva delante diversas estrategias para liberar el fantasma que acosa a su familia. Los últimos planos del documental parecen sugerir, en términos visuales, dicha liberación. Como en The Flat y en Harlan...,los planos finales transcurren en el cementerio: en 2 oder 3 Dinge... vemos una pequeña inscripción en la tumba del nazi: H.E.L. ${ }^{5}$ Quizá el fantasma fue liberado a través del diálogo y la palabra, pero para sus descendientes, Hanns Ludin estará allí presente siempre como una sombra.

\section{A modo de cierre}

Este escrito tuvo como propósito explorar algunas representaciones contemporáneas sobre el Holocausto en el cine documental. Lejos de ser un trabajo exhaustivo, nos propusimos llevar adelante un mapeo, un estado de la cuestión; en esa dirección, es que hemos podido encontrar una diversidad de títulos realizados a partir de estilos y modalidades diversas. Así, hemos podido observar dos grandes tendencias temáticas que a su interior nos permitieron pensar tanto las continuidades como las discontinuidades en cuanto al uso de las herramientas del cine documental para representar este evento histórico.

Uno de los elementos que nos ha llamado la atención es que los documentales dan por sentado el conocimiento sobre el Holocausto por parte del espectador, esto ha permitido entonces que muchas de estas producciones puedan dar lugar a otro tipo de indagaciones, a analizar las imágenes o los efectos en las familias, incluso también se ha dado espacio para representar el trauma en las familias de los perpetradores.

Hemos visto que incluso en los documentales que exponen la historia del Holocausto lo hacen a partir de técnicas novedosas para representarlo. En la era de la memoria global, el Holocausto pareciera haber sido desmitificado permitiendo ser representado como un acontecimiento singular pero no sagrado. Así, los títulos que hemos analizado nos permiten estudiar tanto las tendencias

\footnotetext{
${ }^{5}$ Prager señala que estas iníciales pueden interpretarse de dos maneras: como "Hell" (Hölle), infierno, como al verbo verhehlen, que se refiere a "lo que se oculta" (Prager, 2015, p.169)
} 
del cine documental contemporáneo a la vez que percibir cómo el Holocausto es comprendido actualmente en tanto hecho histórico.

La cantidad de títulos producidos, ya sean de ficción o documental, nos permite reforzar la tesis de la ubicuidad del Holocausto; y con mayor o menos cantidad de películas, año tras años seguiremos, seguramente, observando el estreno de algún film o serie de televisión. En alguna oportunidad, Anton Kaes (1992, p.198) se preguntó si a medida que Hitler lentamente pasaba del reino de la experiencia y de la memoria personal al reino de las imágenes se convertiría en un mero mito cinematográfico. Desde ya que no podemos responder en forma rigurosa esta cuestión, pero si bien el cine de ficción se ha animado a "matar" a Hitler como en Inglourious Basterds (Quentin Tarantino, 2009), lo cierto es incluso también en el cine documental contemporáneo su figura aparece desplazada. Es tiempo ahora de documentar otras historias. 


\section{Bibliografía}

Abraham, N., y Torok, M. (2005). La corteza y el núcleo. Buenos Aires: Amorrortu.

Adams, J., y Vice, S. (Eds.) (2013). Representing Perpetrators in Holocaust Literature and Film. Portland: Vallentine Mitchell.

Apel, D. (2002). Memory Effects: The Holocaust and the Art of Secondary Witnessing. New Jersey: Rutgers University Press.

Avisar, I. (1988). Screening the holocaust: cinema's images of the unimaginable. Bloomington: Indiana University Press.

Boszormenyi-Nagy, I., y Spark, G. (1983). Lealtades invisibles. Buenos Aires: Amorrortu.

Bruzzi, S. (2006). New Documentary. Abingdon: Routledge.

Burucúa, J. E., y Kwiatkowski, N. (2014). "Cómo sucedieron estas cosas". Representar masacres y genocidios. Buenos Aires: Katz.

Cole, T. (2000). Selling the Holocaust: From Auschwitz to Schindler: how History is Bought, Packaged, and Sold. New York: Routledge.

Delage, Ch. (2013). Caught on Camera. Film in the Courtroom from the Nuremberg Trials to the Trials of the Khmer Rouge. Philadelphia: University of Pennsylvania Press. 
Hirsch, M. (2012). The Generation of Postmemory. New York: Columbia University Press.

Huyssen, A. (2001). En busca del futuro perdido. Buenos Aires: Fondo de Cultura Económica.

Insdorf, A. (2002). Indelible Shadows: Film and the Holocaust. Cambridge Cambridge University Press.

Kaes, A. (1992). Fron Hitler to Heimat. Cambridge: Harvard University Press.

Levy, D., y Sznaider, N. (2006). The Holocaust and Memory in the Global Age. Philadelphia: Temple University Press.

Nichols, B. (1997). La representación de la realidad. Barcelona: Paidós.

Nichols, B. (2001). Introduction to Documentary. Bloomington: Indiana University Press.

Novick, P. (2000). The Holocaust in American Life. New York: Mariner Books.

Paget, D. (2011). No other way to tell it. Docudrama on Film and Television. New York: Manchester University Press.

Plantinga, C. (1997). Rhetoric and Representation in Nonfiction Film. New York: Cambridge University Press.

Posner, G. (1991). Los hijos de Hitler. Buenos Aires: Planeta.

Prager, B. (2015). After the Fact. The Holocaust in Twenty-First Century Documentary Film. New York: Bloomsbury Academic.

Rees, L. (2005). The Nazis: A Warning from Histor. En T. Haggith y J. Newman (Eds.).

Cuadernos Judaicos ISSN: 0718-8749 
Holocaust and the Moving Image. Representations in film and television since 1933 (pp.146153). London: Wallflower.

Renov, M. (2004). The Subject of Documentary. Minneapolis: University of Minnesota Press.

Resha, D. (2015). The Cinema of Errol Morris. Middletown: Wesleyan University Press.

Rosenfeld, A. H. (1997). The Americanization of the Holocaust. En A. H. Rosenfeld (Ed.). Thinking about the Holocaust. After half a century (pp.119-150). Bloomington: Indiana University Press.

Sánchez-Biosca, V. (2006). Cine de historia, cine de memoria: la representación y sus límites. Madrid: Cátedra.

Saxton, L. (2008). Haunted Images. Film, Ethics, Testimony and The Holocaust. London: Wallflower Press.

Sibilia, P. (2008). La intimidad como espectáculo. Buenos Aires: Fondo de Cultura Económica.

Traverso, E. (2008). De la memoria y su uso crítico. Barcelona: Generalitat de Catalunya.

Welzer, H., Moller, S., y Tschuggnall, K. (2012). Mi abuelo no era nazi. El nacionalsocialismo en la memoria familiar. Buenos Aires: Prometeo.

Cuadernos Judaicos ISSN: 0718-8749 